\title{
DNA Damage Caused by Polycyclic Aromatic Hydrocarbons: Mechanisms and Markers
}

\author{
Balam Muñoz and Arnulfo Albores \\ Departamento de Toxicología,
}

Centro de Investigación y de Estudios Avanzados del I.P.N.

México

\section{Introduction}

Polycyclic Aromatic Hydrocarbons (PAHs) are a group of chemicals that occur naturally in coal, crude oil and gasoline. Incomplete combustion of organic material results in emission of PAHs (ATSDR, 1996). These molecules consist of two or more aromatic rings fused in linear, angular or cluster arrangements (Fig. 1) and by definition are composed of hydrogen and carbon. PAHs containing up to six fused aromatic rings are often known as "small" PAHs while those containing more than six aromatic rings are called "large" PAHs. As pure chemicals, these compounds are colorless, white or pale yellow solids. Their physicochemical properties, vapor pressure and solubility vary according to their molecular weight. PAHs possess a highly characteristic UV absorbance spectra although some may be fluorescent (Fetzer \& Biggs, 1994). PAHs are ubiquitous and persistent as a consequence of natural (forest fires and volcanic eruptions) and human activities (Jongeneelen, 2001). PAHs may distribute in water, soil and the atmosphere according to different weather and geographical factors. Although industrial activity such as coke manufacturing or asphalt production are major contributors to $\mathrm{PAH}$ emissions, incineration, power generation and several mobile sources also emit a considerable amount of PAHs. Significant sources of PAHs in surface waters include deposition of airborne PAHs, municipal wastewater discharge, urban storm-water runoff, and industrial waste. Food groups that tend to have the highest levels of PAHs include charcoal broiled or smoked meats, leafy vegetables, grains, and vegetable fats and oils (Yu, 2005). Therefore, workers of these industries and the general population are continually exposed to different concentrations of PAH mixtures. The Agency for Toxic Substances and Disease Registry (ATSDR) has grouped 17 PAHs according to their health effects (ATSDR, 1996). The United States Environmental Protection Agency (EPA) has designated 28 PAH compounds as priority pollutants (EPA, 2009) (Table 1). The International Agency for Research on Cancer (IARC) has classified some these compounds as carcinogenic (group 1) or likely carcinogenic (group 2A) to humans, for example benzo $[a]$ pyrene and dibenz $[a, h]$ anthracene, respectively (IARC, 2010). Finally, the National Institute of Standards and Technology has created a classification of PAHs according to their symbols, molecular formulas, class and notation among other properties (NIST, 2010).

The most common mechanism of carcinogenesis induced by PAHs is DNA damage through the formation of adducts. Alternatively, in the presence of reactive oxidative species, DNA 
damage can also result. In this chapter, we review the mechanisms of damage caused by exposure to PAHs, factors involved in repairing the damage, and the important role of biomarkers.

\section{Metabolism of PAHs}

Once PAHs enter the body they are metabolized in a number of organs (including liver, kidney, lungs), excreted in bile, urine or breast milk and stored to a limited degree in adipose tissue. The principal routes of exposure are: inhalation, ingestion, and dermal contact. The lipophilicity of PAHs enables them to readily penetrate cellular membranes (Yu, 2005). Subsequent metabolism renders them more water-soluble making them easier for the body to remove. However, PAHs can also be converted to more toxic or carcinogenic metabolites.

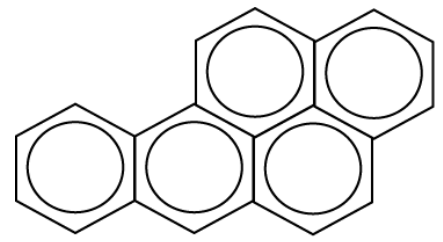

Benzo[a]pyrene

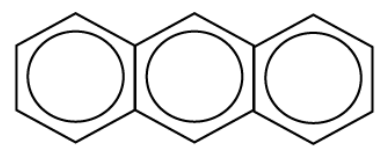

Anthracene<smiles>c1ccc2ccccc2c1</smiles>

Naphtalene<smiles>c1cc2ccc3ccc4ccc5ccc6ccc1c1c2c3c4c5c61</smiles>

Coronene

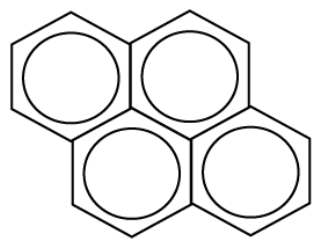

Pyrene

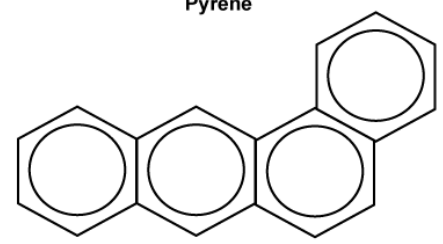

Benzo[a]anthracene

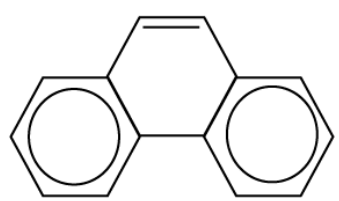

Phenantrene<smiles>c1cc2ccc3ccc4ccc5ccc6ccc7ccc8ccc1c1c2c3c4c5c6c7c81</smiles>

Ovalene

Fig. 1. Structures of some polycyclic aromatic hydrocarbons. 


\begin{tabular}{|l|l|l|l|}
\hline \multicolumn{1}{|c|}{ Name } & \multicolumn{1}{|c|}{ CAS1 } & \multicolumn{1}{c|}{ Name } & \multicolumn{1}{c|}{ CAS } \\
\hline Acenaphthene & $83-32-9$ & Dibenz(a,j)acridine, & $224-42-0$ \\
\hline Acenaphtylene & $208-96-8$ & Dibenzo(a,h)anthracene & $53-70-3$ \\
\hline Benzo(a)anthracene & $56-55-3$ & Dibenzo(a,e)fluoranthene & $5385-75-1$ \\
\hline Benzo(a)phenanthrene (chrysene) & $218-01-9$ & Dibenzo(a,e)pyrene & $192-65-4$ \\
\hline Benzo(a)pyrene & $50-32-8$ & Dibenzo(a,h)pyrene & $189-64-0$ \\
\hline Benzo(b)fluoranthene & $205-99-2$ & Dibenzo(a,l)pyrene & $191-30-0$ \\
\hline Benzo(j)fluoranthene & $205-82-3$ & 7H-Dibenzo(c,g)carbazole & $194-59-2$ \\
\hline Benzo(k)fluoranthene & $207-08-9$ & 7,12-Dimethylbenz(a)anthracene & $57-97-6$ \\
\hline Benzo(g,h,i)perylene & $191-24-2$ & Fluorene & $86-73-7$ \\
\hline Benzo(j,k)fluorene (fluoranthene) & $206-44-0$ & Indeno(1,2,3-cd)pyrene & $193-39-5$ \\
\hline Benzo(r,s,t)pentaphene & $189-55-9$ & 3-Methylcholanthrene & $56-49-5$ \\
\hline Dibenz(a,h)acridine & $226-36-8$ & 5-Methylchrysene & $3697-24-3$ \\
\hline Phenanthrene & $85-01-8$ & Pyrene & $129-00-0$ \\
\hline 1-Nitropyrene & $5222-43-0$ & Anthracene & $120-12-7$ \\
\hline
\end{tabular}

Table 1. US EPA priority polycyclic aromatic hydrocarbons.

After exposure, these molecules induce expression of phase I and II metabolizing enzymes (Shimada, 2006) including aldo-ketone reductases, cytochrome P-450s, catechol-Omethyltransferase, epoxide hydrolase, peroxidases, glutathione S-transferases, Nacetyltransferases, sulfotransferases, and other enzymes catalyzing conjugation reactions (Williams \& Phillips, 2000).

\subsection{Phase I metabolism of PAHs}

There are three main pathways for activation of PAHs: the formation of a PAH radical cation in a metabolic oxidation process involving cytochrome P450 peroxidase, the formation of PAH-o-quinones by dihydrodiol dehydrogenase-catalyzed oxidation and finally the creation of dihydrodiol epoxides, catalyzed by cytochrome P450 enzymes (Guengerich, 2000). The most common mechanism of metabolic activation of PAHs, such as benzo[a]pyrene $(\mathrm{B}[\mathrm{a}] \mathrm{P})$, is via the formation of bay-region dihydrodiol epoxides e.g. benzo[a]pyrene-7,8-dihydrodiol-9,10-epoxide (BPDE), via CYP450 and epoxide hydrolase (EH) (Fig. 2). The most important enzymes in the metabolism of PAHs are CYPs 1A1, 1A2, $1 \mathrm{~B} 1$ and 3A4. CYP1A1 is highly inducible by PAHs such as B[a]P and some polyhalogenated hydrocarbons. Recombinant human CYP1A1 metabolizes compounds such as B[a]P, 2acetylaminofluorene and 7,8-diol,7-12-dimethylbenz[a]anthracene (Kim, et al., 1998). CYP1A2 and CYP1B2 are also inducible by the exposure to PAHs. In fact, these enzymes share the same mechanism with which PAH molecules interact with, the aryl hydrocarbon receptor $(\mathrm{AhR})$. The $\mathrm{AhR}$ is present in the cytoplasm as a complex with other proteins such as heat shock protein 90 (Hsp90), p23 and AhR-interacting protein. After forming a complex with PAHs, the Hsp90 is released and the AhR-PAH complex translocates to the nucleus (Fig 3). Here, it creates a heterodimer with a ARNT (Ah Receptor Nuclear Translocator) and

${ }^{1}$ CAS (Chemical Abstracts Service) registry number 
afterwards binds to DNA via the xenobiotic response element (XRE) situated in the promoter region of CYP1A and CYP1B genes (Shimada, et al., 2002)). CYP3A4 and CYP3A5 are known to activate PAHs present in cigarette smoke, such that increased protein levels and activity of these enzymes in cells exposed to smoke have been detected (Piipari, et al., 2000)). Furthermore, genetic variants of CYPs are associated with risk of carcinogenesis. Some polymorphisms of CYP1A1 are associated with adduct formation and mutagenesis in several populations and species (Ichiba, et al., 1994, Rojas, et al., 2000, Shields, et al., 1992). This fact is related to the metabolizing rate and the subsequent repair mechanism associated with DNA damage. Polycyclic aromatic hydrocarbons are activated by a pathway that involves both CYP enzymes and epoxide hydrolase.

Other phase I enzymes related to PAHs metabolism are the aldo-keto reductases. These enzymes oxidize polycyclic aromatic $(\mathrm{PAH})$ trans-dihydrodiols to reactive and redox-active o-quinones in vitro (Quinn \& Penning, 2006). Specifically, AKR1A1, and members of the AKR1C dihydrodiol/hydroxysteroid dehydrogenase subfamily, AKR1C1-AKR1C4 are involved in metabolic activation of PAH trans-dihydrodiol. Production of o-quinone metabolites by these enzymes has been shown in vitro and in cell lines to amplify ROS and oxidative damage to DNA bases to form the highly mutagenic lesion 8-oxo-dGuo and render damaged and carcinogenic DNA (Quinn, et al., 2008).

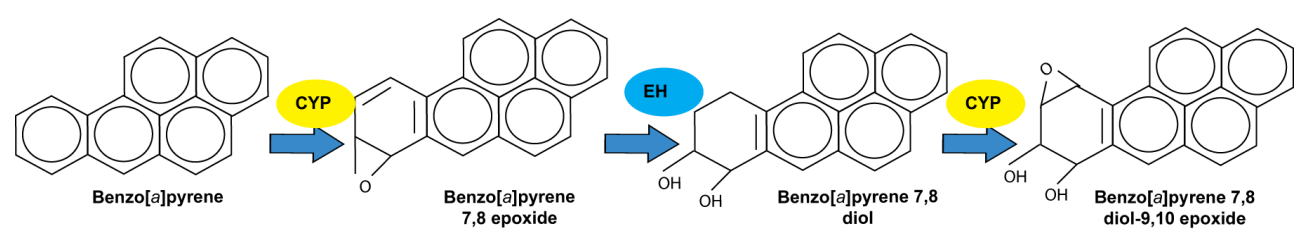

Fig. 2. Mechanism of activation of BaP by cytochrome P450 (CYP) and epoxide hydrolase $(\mathrm{EH})$.

\subsection{Phase II metabolism of PAHs}

Phase II metabolism includes conjugation of metabolites from phase I with small molecules catalyzed by specific enzymes such as sulfotransferases (SULTs), UDP-glucuronyl transferases (UGTs) or glutathione S-transferases (GSTs). SULTs have been shown to activate some metabolites of PAHs such as 7,12-dimethylbenz[a]anthracene and its methyl-hydroxylated derivatives, in different tissues (Chou, et al., 1998). Polymorphisms of SULT1A1 have been associated with PAH-DNA adduct levels (Tang, et al., 2003). Glucuronidation is also a main pathway for PAH detoxification metabolism. Like sulfation, glucuronidation produces polar conjugates that are readily excreted. Oxygenated benzo[a]pyrene derivatives are common substrates of UDP-glucuronyltransferase (Bansal, et al., 1981), the resulting metabolite, 1hydroxypyrene glucuronide, and the parental 1-hydroxypyrene are used as biomarkers of PAH exposure (Strickland, et al., 1994). Finally, GSTs are also involved in conjugation of PAH derivatives. The importance of this activity has been demonstrated in vitro using the 
corresponding diol epoxides of dibenzo[ $[a, l]$ pyrene and benzo[a]pyrene as substrates for these enzymes (Sundberg, et al., 2002). Activity of GSTs is related to their glutathione redox status and genotoxic damage, at least in placenta tissue, therefore this status can be used as biomarker of PAH exposure (Obolenskaya, et al., 2010). On the other hand, polymorphisms of phase II metabolism are associated with carcinogenesis and with DNA damage. For instance, there is an important association between GSTM1 gene polymorphism and the DNA adduct levels (Binkova, et al., 2007). GSTs are also important for quenching and detoxifying ROS and their derivatives (Bonner, et al., 2005).

\section{Mechanisms of damage}

PAHs undergo metabolic activation to diol-epoxides as we discussed before, which bind covalently to DNA. Afterwards, they form adducts or induce oxidative stress that provokes mutations. If DNA repair mechanisms are afflicted by the adduct formation rate the result is an accumulation of mutations in DNA that may induce carcinogenesis. Several studies indicate that the number of adducts formed is related to the degree of PAH exposure. However, is also important to consider the effect of life stage of the organism at exposure to PAHs (Bolognesi, et al., 1991), as well as concentration and genetic profiles of PAHs, among other factors. PAH exposure induces several molecular and cellular responses that modify the endogenous environment. Exposure to PAHs induces genes involved in apoptosis, cell cycle control and DNA repair (Castorena-Torres, et al., 2008).

\subsection{Adduct formation}

When PAHs are metabolized reactive diol epoxide enantiomers are generated. These enantiomers form DNA adducts with different structures, motifs and biological activities. DNA adducts of diverse conformations are excised by DNA repair enzymes at different rates. PAH diol epoxides (PAHDEs) bind covalently to exocyclic amino groups of guanine and adenine, forming stable adducts within DNA (Lin, et al., 2001). Futhermore, there are correlations between DNA adduct levels and mutagenesis. The structure of some PAHDEs forms a region called "Fjord", which some studies indicate is a region that is highly involved with high tumorigenicity. These molecules are mostly non-planar, reactive, and bind preferentially to adenine nucleotides. On the other hand, PAHDES with a "bay" region are planar, less reactive and bind to guanine nucleotides (Fig. 4). Geacintov and colleagues (1997) have described several structural motifs by nuclear magnetic resonance analysis. These structural types are divided into: (a) minor groove, when the $\mathrm{PAH}$ is partially accessible to the solvent; (b) classical intercalation, when the PAH is protected from the environment and forms a "sandwich structure" and (c) base-displaced intercalation, when PAHs substitute the healthy base (Buterin, et al., 2000, Geacintov, et al., 1997).

Molecular studies have revealed that adducts in DNA block polymerase replication activity, contributing to increased DNA damage by reducing repair activity (Hsu, et al., 2005). An example of adduct formation between adenine or guanine and benzopyrene diol epoxide (BPDE) is shown in Figure 5. Interestingly, some compounds present in food are capable of preventing adducts such as ellagic acid (EA) by the formation of adducts previous to DNA binding (Lagerqvist, et al., 2011). The presence of adducts have been evaluated in marine and aquatic species as an indicator of environmental occurrence of PAHs. Some studies have revealed, by X-ray crystallography, structures of PAH-adducted oligonucleotides bound to bacterial DNA polymerases (Hsu, et al., 2005, Ling, et al., 2004). 


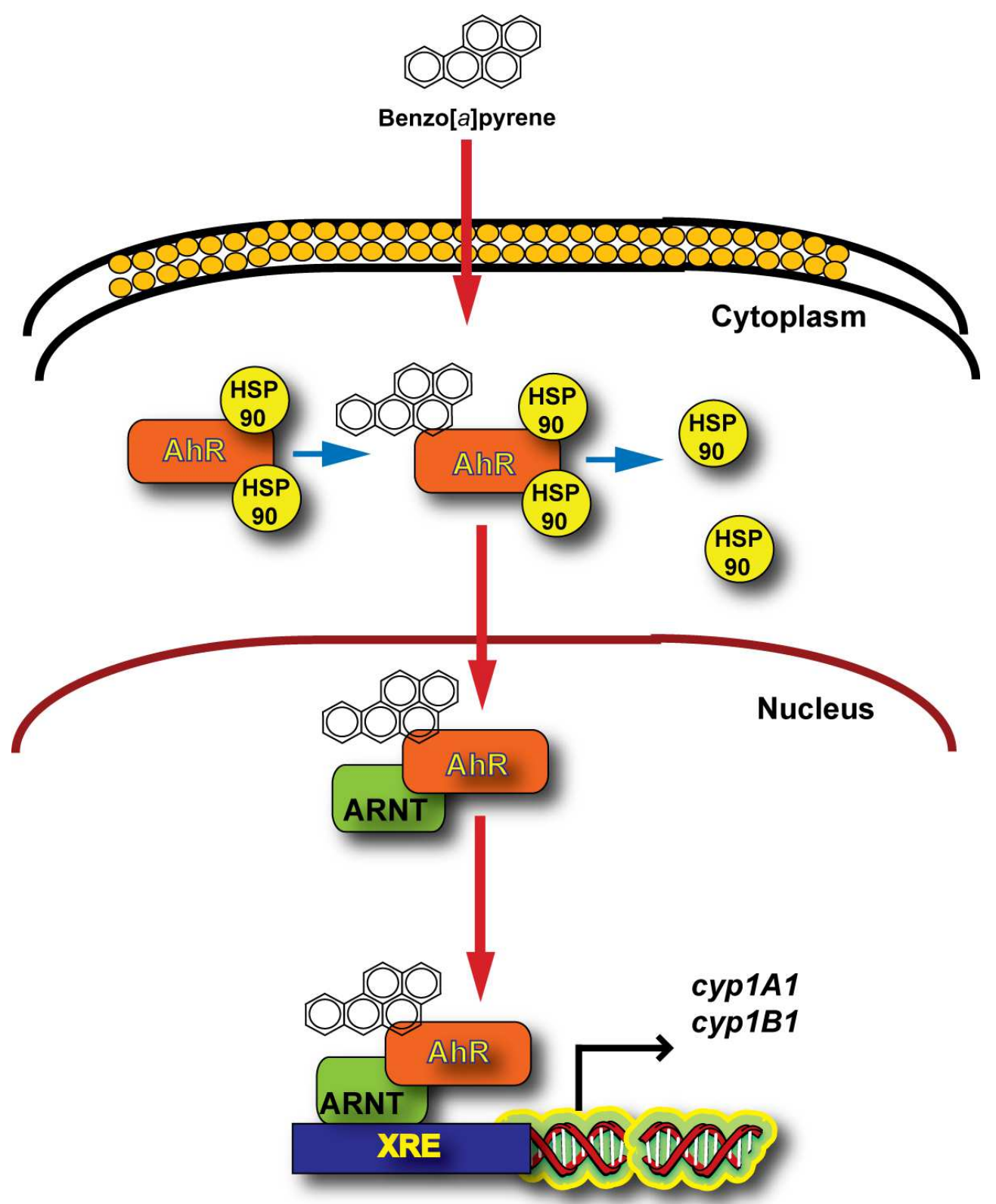

Fig. 3. Aryl hydrocarbon receptor (AhR) pathway activated by BaP induces expression of cyp1A1 and cyp1B1. 


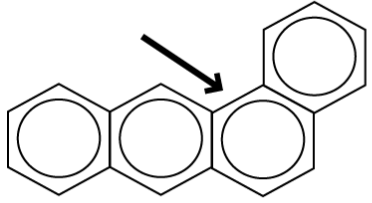

"Bay" structure

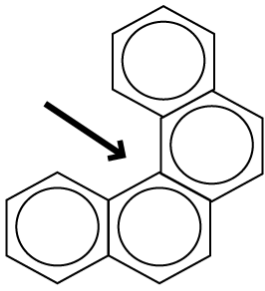

"Fjord" structure

Fig. 4. Difference between bay and fjord regions in two PAH conformations.

\subsection{Oxidative stress}

It has been reported that $\mathrm{BaP}$ derivatives have the capacity to enter redox cycles and induce the production of reactive oxygen species (ROS), thereby causing oxidative stress (An, et al., 2011). BaP radical-cations are precursors for 6-OH-BaP. Auto-oxidation of this derivative may result in the formation of $\mathrm{BaP}$ quinones such as 6, 12-, 1,6- and 3,6-BaP dione (Briede, et al., 2004). These metabolites can undergo redox-cycling to their corresponding BaP diols and produce superoxide reactive oxygen species which are then converted to hydroxyl radicals by the Haber-Weiss reaction (Lesko \& Lorentzen, 1985). Free radicals react with guanine and cause DNA damage, including the production of 7-hydro-8-oxo-20-deoxyguanosine (8-oxodG) (Chatgilialoglu \& O'Neill, 2001). The OGG1 gene codes for a DNA glycosylase involved in base excision repair of 8-oxo-dG that arises from ROS. When this system fails there is an increase in mutation rate (Bonner, et al., 2005). Balance between generation of ROS species and scavenging of these molecules is fundamental in repairing DNA damage. If the rate of ROS generation is greater than their removal it is likely that more DNA damage will result. PAHs may absorb light energy in UVR (280-400 $\mathrm{nm})$ region and may induce DNA damage by production of ROS. For example, chrysene, induces apoptosis and DNA damage in human keratinocytes by generating ROS in response to UVB radiation (Ali, et al., 2011).

\subsection{Mutations}

The failure of repair mechanisms and constant exposure to PAHs induce mutagenesis in cells. These mutations are present in multiple genes including those that participate in cell survival. In particular, p53 mutations are associated with risk of carcinogenesis in PAHexposed individuals. Since the p53 protein is a transcription factor that regulates cell proliferation, differentiation, apoptosis, and DNA repair, mutations induced in this important protein could lead to severe damage in cells and genes. Some studies have associated p53 mutations to PAH exposure (Mordukhovich, et al., 2010, Yoon, et al., 2003). Another common target of mutagenesis is the ras gene (Ross \& Nesnow, 1999). A study by Gray et al. (2001) revealed that exposure to BaP in mice increases mutation of the K-ras gene.

\subsection{Carcinogenesis}

Forming adducts in DNA repair-related genes is not the only mechanism by which PAHs induce carcinogenesis. An additional danger amounts from their resemblance to steroid hormones allowing PAHs the ability to activate estrogen receptors and metabolism. The ability of several PAHs to displace natural estrogens and occupy ER binding sites, at least to some extent, implies a potential mechanism of action in endocrine tissues that is ER- 
mediated (Santodonato, 1997). Nevertheless, the most important mechanism of carcinogenesis is a deficient DNA repair system in key genes involved in cell cycle control. Since chronic exposure to PAHs is related to a high rate of mutagenesis it is probable that damage to DNA is cumulative. Several studies have associated chronic occupational PAH exposure to multiple types of cancer including cancer of the bladder, lung, kidney, liver, and breast (Boffetta, et al., 1997, Dickey, et al., 1997, Karami, et al., 2011, Shen, et al., 2003).

A

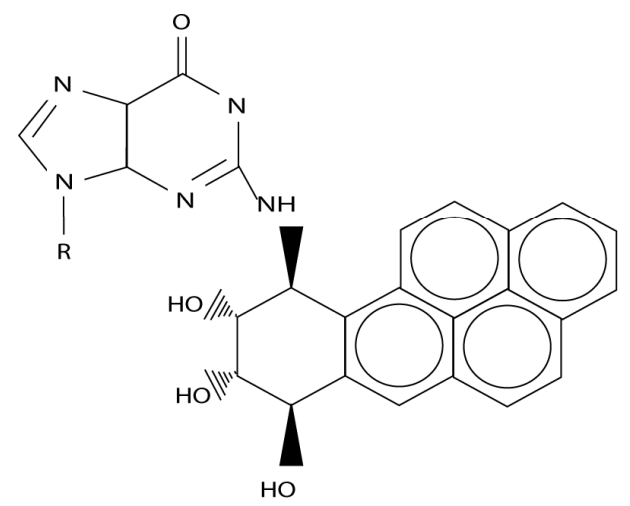

B

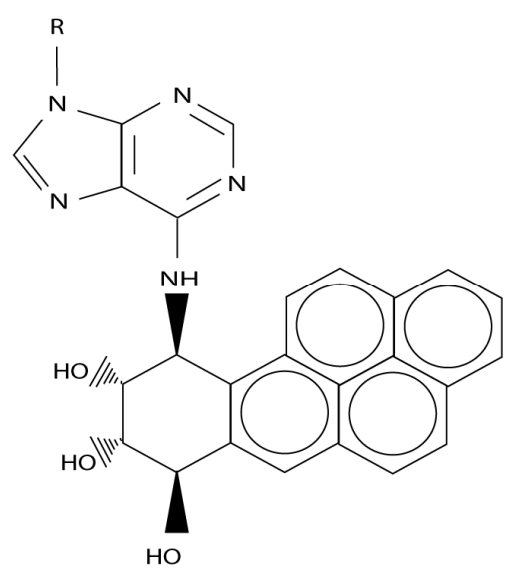

Fig. 5. Structures and interaction of two common adducts: (A) BPDE-dG adduct and (B) BPDE-dA adduct.

\section{Mechanisms of repair}

Several molecular processes exist in cells that repair damage caused from $\mathrm{PAH}$ exposure, adduct formation, and ROS production. If the damage is repaired by these mechanisms no further consequences should result. However, if the lesions escape repair and survive to the next round of DNA replication faulty translesion bypass can occur causing mutagenesis and carcinogenesis. The most common mechanisms of repair used by cells exposed to PAHs are: nucleotide excision repair (NER), base excision repair (BER), non-homologous end joining (NHEJ) of DNA double-strand breaks (DSBs), homologous recombinational repair (HRR) and transcription coupled repair (TCR). On the other hand, some studies indicate that DNA damage induced by PAHs is preferentially repaired by NER or BER (Braithwaite, et al., 1998), and to a lesser extent by HRR (Meschini, et al., 2010).

\subsection{Nucleotide excision repair (NER)}

In this process, cells recognize damaged DNA regions based on their abnormal structure or chemistry, then excise and replace them. This pathway is complex, requiring more than 20 different proteins. NER is considered the main pathway for removal of bulky DNA adducts (Braithwaite, et al., 1998). There are two distinct forms of NER: GG-NER (Global GenomicNER) and TC-NER (Transcription Coupled-NER). The first corrects damage in transcriptionally silent areas of the genome, while the second repairs lesions on the actively transcribed strand of the DNA. In GG-NER, the XPC (Xeroderma Pigmentosum Complementation Group-C)/hHR23B ( $\operatorname{Rad} 23$ homolog B) protein complex is responsible for 
the initial detection of damaged DNA. On the other hand, TC-NER does not require XPC, however the stalled RNA Polymerase complex is displaced in order to allow the NER proteins to access the damaged DNA. After this process, TC-NER and GG- NER proceed in identical ways. XPA and RPA (Replication Protein-A) then bind at the location of injury and further aid in damage detection. Subsequently, the XPB and XPD helicases unwind the DNA duplex in the surrounding area of the lesion. The endonucleases XPG and ERCC1 (Excision Repair Cross-Complementing group-1)/XPF then cleave one strand of the DNA at positions 3 ' and 5' to the damage, respectively, generating a 30 base oligonucleotide containing the lesion. This oligonucleotide is displaced, permitting gap repair synthesis (performed by DNA Pol Delta/Epsilon, and other accessory proteins). Finally, DNA ligase seals the nick in the repaired strand (Fig. 6). Several studies demonstrate that certain polymorphisms in NER genes alter the efficiency of DNA repair (Shen, et al., 2006, Vodicka, et al., 2004). Four polymorphisms, XPA 4G/A (rs1800975), ERCC1 C8092A (rs3212986), XPD Lys751Gln (rs1052559), and XPF Ser835Ser (rs1799801), are associated with a reduced capacity for DNA repair and an increased susceptibility to various cancers (Hu, et al., 2004, Monzo, et al., 2007). However, a recent study reports that significant opportunities exist for an interaction between the XPA-4 G/A polymorphism and PAH exposure on sperm DNA damage (Gu, et al., 2010). Although some PAHs lack "bay" and/or "fjord" regions, such as anthracene for example, this molecule also induces DNA damage, activating repair mechanisms, and has in fact has been shown to induce NER and MMR pathways (Desler, et al., 2009). These findings provide support for the importance of NER pathway in DNA damage induced by PAHs.

\subsection{Base excision repair (BER)}

BER involves the combined activity of some specific proteins that recognize and excise DNA damage, replacing the damaged moiety with normal nucleotides. PAH adducts are repaired by this mechanism. BER consists of three important steps: first, removal of the incorrect base by an appropriate DNA N-glycosylase to create an AP site (apurinic/apyrimidinic site); second, cutting off the damaged DNA strand by AP endonuclease upstream of the AP site, therefore creating a 3'-OH terminus adjacent to the AP site and finally, extension of the 3'$\mathrm{OH}$ terminus by DNA polymerase, accompanied by excision of the AP site. Several enzymes are required to complete these three steps. In humans, there are at least six different glycosylases that bind specifically to a target base and hydrolyze the N-glycosylic bond generating the AP or abasic site. Next, the AP site is processed by the APE1 system (AP Endonuclease-1, or HAP1/REF1/APEX), which cuts the phosphodiester backbone adjacent to the $5^{\prime}$ end of the AP site, resulting in a $3^{\prime}$ hydroxyl group and a transient $5^{\prime} \mathrm{dRP}$ (abasic deoxyribose phosphate). The removal of the dRP is accomplished by DNA Pol Beta (polymerase beta) activity, which adds one nucleotide to the $3^{\prime}$ end of the nick and removes the dRP moiety through the action of an AP lyase (Bennett, et al., 1997). DNA Pol Beta also interacts with XRCC1. DNA Pol Beta is therefore crucial for the inclusion of different components of BER at sites of DNA damage and promoting repair efficiency (Fig. 6). The BER pathway deals with smaller damage to individual bases, such as oxidation, methylation, depurination, and deamination. If the adducts are left unrepaired, they may cause permanent mutations (Boysen \& Hecht, 2003). If these mutations are situated at critical sites, including tumor suppressor genes, DNA repair-related genes or oncogenes, they may lead to cellular transformation and the development of tumors. A recent study demonstrates that BER plays an important role in DNA repair in cells exposed to PAHs. Chinese hamster ovary cells $(\mathrm{CHO})$ deficient in the BER pathway were found to be more 
sensitive to damage induced by DBPDE, as measured by frequency of chromosomal aberrations (Meschini, et al., 2010). Polymorphisms in proteins of the BER pathway are associated with an increase in DNA damage. One of these proteins, XRCC1, was discovered to have four functional polymorphisms: T-77C, Arg194Trp, Arg280His and Arg399Gln, associated with alteration in repair capacity of DNA damage induced by PAH adducts (Ji, et al., 2010).

\subsection{Homologous recombination (HR)}

Homologous recombination (HR) is a DNA metabolic process found in all forms of life that provides high-fidelity, template-dependent repair or tolerance of complex DNA damage including DNA gaps, DNA double-stranded breaks (DSBs), and DNA interstrand crosslinks (ICLs). The primary function of HR is to search for homology and DNA strand invasion through the Rad51-ssDNA presynaptic filament by positioning the invading 3'-end on a template duplex DNA to initiate repair synthesis. This mechanism participates in DNA repair induced by three specific PAHs: 1-nitrosopyrene (1-NOP), N-acetoxy-2acetylaminofluorene (N-AcO-AAF), and 4-nitroquinoline 1-oxide (4-NQO). These PAHs were compared for their ability to cause intrachromosomal homologous recombination between two identical genes stably integrated into a genome of a mouse cell. In each case a dose-dependent increase in recombination frequency with differences in the efficiency of each compound was observed (Bhattacharyya, et al., 1989). Polymorphisms in the proteins related to the HR seem to be associated with a protective effect against PAH exposure.

One of these proteins, XRCC3, participates in homologous recombination repair of DNA double strand breaks and cross-links. This factor is a member of a family of Rad-51-related proteins. According to Shen, et al. (2003), it plays a protective role against bladder cancer for the XRCC3 codon 241 polymorphism, a higher risk in smokers. Considering that tobacco smoke has a high concentration of PAHs, this finding suggests that HR is related to some extent in the repair of damaged DNA induced by PAH exposure. Moreover, in an in vitro study using $\mathrm{CHO}$ cells deficient in the HR pathway, these cells were more sensitive to PAH exposure suggesting that this mechanism plays an important role in DNA repair (Meschini, et al., 2010).

\subsection{Translesion synthesis (TLS)}

To avoid cell death that may occur as a result of arrested DNA replication at unrepaired lesions cells have a mechanism, referred to as translesion synthesis (TLS), which allows them to overcome replication blockage from DNA damage. Once the lesion is generated in the DNA, the replication machine stalls, followed by either lesion repair or bypass by specialized polymerases (DNA polymerase IV or V, from the $\mathrm{Y}$ Polymerase family). Polymerase switching is mediated by, among other factors, the protein PCNA. TLS polymerases often have low fidelity; however, they are highly efficient, inserting the correct nucleotides at specific sites of damage. This process has been studied using the TLS performed by Sulfolobus solfataricus DNA polymerase Dpo4. The analysis of an oligonucleotide primer-extended and its $\mathrm{dA}-\mathrm{PAH}$ adducts, using a liquid chromatography (LC)-mass spectrometry (MS)/MS, revealed this process in-depth including other proteins that may be involved (Zang, et al., 2006). The structure and nature, among other properties, of TLS polymerases is related to their fidelity and efficiency (Rechkoblit, et al., 2002). For a complete review of this process and the role of PAH adducts we recommend a review of Eoff et al. (2010). 

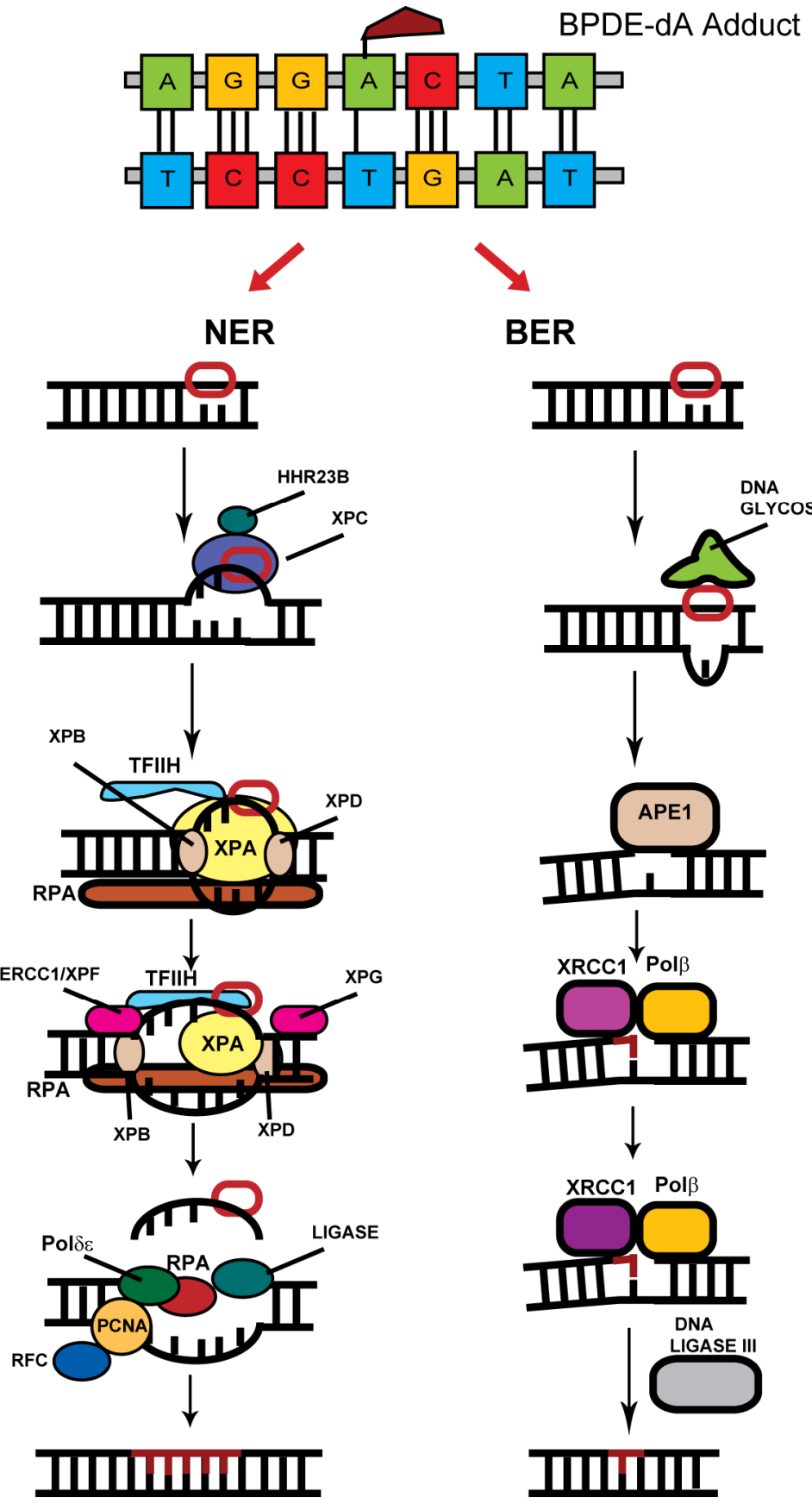

BER
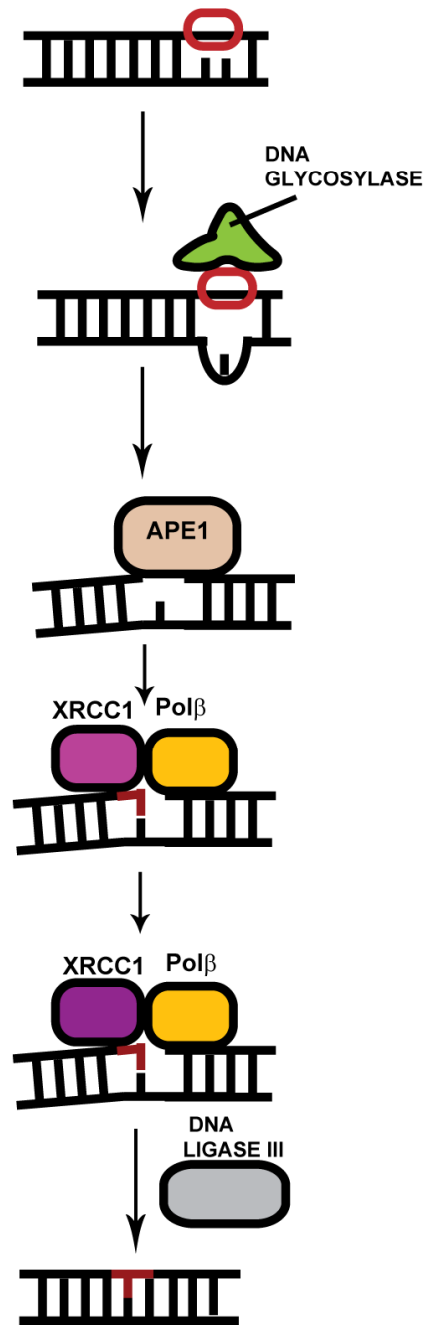

Fig. 6. Common mechanisms of DNA repair from PAH exposure and adduct formation: nucleotide excision repair (NER) and base excision repair (BER). 


\subsection{Mismatch repair (MMR)}

The MMR system is responsible for the post-replicative repair of mismatches and small single stranded DNA loops, and is essential to the prevention of recombination between homologous DNA sequences. Although MMR repair in eukaryotic cells is not fully understood, studies of this mechanism in bacteria have contributed considerably to our understanding of this pathway. MMR is dependent on three highly conserved proteins: MutS, MutL, and MutH. In eukaryotes, homologous proteins as PCNA, RPA, HMGB1, RFC, and ligase I participate and coordinate the MMR process. Eukaryotic cells that are deficient in MMR have a 10-1,000-fold increase in mutation rates (Kunkel \& Erie, 2005). In another study, MMR deficient mice showed an increase in PAH-induced lymphoma compared to controls (Zienolddiny, et al., 2006). MMR corrects strand-specific base mispairs and small loop structures. Furthermore, this mechanism recognizes smaller base analoges as mispairs that are participating in oxidative DNA damage repair. Cells deficient in the hMLH1 protein (essential for MMR initiation) have a reduced repair activity when exposed to anthracene (Desler, et al., 2009). This result indicates that MMR has a probable role in DNA repair response resulting from $\mathrm{PAH}$ exposure.

\subsection{Other repair mechanisms}

Further studies are necessary to confirm two other possible mechanisms involved in DNA repair following PAH exposure: non-homologous end joining (NHEJ) and transcription coupled repair (TCR). NHEJ appears to participate in DNA repair after PAH exposure. A recent report described that the V3-3 CHO cell line (NHEJ-deficient), showed a statistically significant dose-dependent enhancement during induced sister chromatid exchanges under PAH exposure. This result indicates that this process is important in DNA repair (Meschini, et al., 2010).

Some adducts perform alterations to the transcription process. The current model for TCR is dependent on the stalling of RNA pol II. Some PAHs such as BPDE and B[c]PhDE produce adducts repaired by TCR, while other studies indicate that PAHs such as B[g]Ch-DE and $\mathrm{DB}[\mathrm{a}, 1] \mathrm{P}-\mathrm{DE}$ also produce adducts. The efficiency and rate for repairing DNA depends of intrinsic adduct properties (Zhong, et al., 2010). For a complete review of this process we suggest consulting Scicchitano (2005).

\section{Methods for detection of DNA damage}

DNA damage associated with PAH exposure is mainly assessed by measuring the number of adducts formed. Several methods, such as ${ }^{32} \mathrm{P}$-postlabelling or immunochemical analysis with specific antibodies, have been applied extensively. However, the arrival of new molecular techniques and innovations in previously well-established biochemical methods, have increased the possibility of the early detection of DNA damage. Polymorphisms and gene expression analysis are helping to determine susceptibility of individuals and populations. Use of mass spectrometry and high performance liquid chromatography (HPLC) with increased sensitivity is another common tool to evaluate and quantify adduct formation. A brief description of the available methods to detect DNA damage is listed in Table 2.

On the other hand, some studies have proposed using molecules included in natural compounds to reduce DNA damage induced by PAHs (Chan, et al., 2003). Green tea consumption may reduce the risk of lung cancer by several hypothesized mechanisms 
including scavenging oxidative radicals (Bonner, et al., 2005). In previous studies, the role of green tea polyphenols has been associated with protective effects against tumor induction in mice to which PAHs were topically applied (Wang, et al., 1989). Resveratrol (Leung, et al., 2009) and Genistain (Leung, et al., 2009) reduced DNA oxidative damage and adduct formation induced by 7,12-dimethylbenz[a]anthracene in MCF-10A cells.

\begin{tabular}{|c|c|c|c|c|}
\hline $\begin{array}{l}\text { Strategies for } \\
\text { detection of } \\
\text { PAH exposure }\end{array}$ & $\begin{array}{l}\text { Target molecule } \\
\text { or experimental } \\
\text { technique }\end{array}$ & Advantages & Disadvantages & Examples \\
\hline $\begin{array}{c}\text { Metabolites } \\
\text { detection and } \\
\text { quantitation }\end{array}$ & $\begin{array}{l}\text { Metabolites as a } \\
\text { result of exposure } \\
\text { detected by } \\
\text { chromatography }\end{array}$ & $\begin{array}{l}\text { Sensitive methods and } \\
\text { multiple biological } \\
\text { sources }\end{array}$ & $\begin{array}{l}\text { Unstable } \\
\text { metabolites }\end{array}$ & 1-hydroxypyrene \\
\hline \multirow{4}{*}{$\begin{array}{c}\text { Adduct } \\
\text { detection }\end{array}$} & $\begin{array}{l}\text { Radiolabeled } \\
\text { compounds }\end{array}$ & $\begin{array}{l}\text { High sensitive to stable } \\
\text { adducts }\end{array}$ & $\begin{array}{l}\text { It may not be } \\
\text { possible to detect } \\
\text { unstable } \\
\text { adducts }\end{array}$ & \multirow{4}{*}{ DNA adducts } \\
\hline & $\begin{array}{l}\text { Mass } \\
\text { spectrometry }\end{array}$ & $\begin{array}{l}\text { High sensitivity and } \\
\text { selectivity }\end{array}$ & \begin{tabular}{|l|} 
Suitable just for \\
isotopes
\end{tabular} & \\
\hline & $\begin{array}{l}\text { 32P-Postlabeling } \\
\text { assay }\end{array}$ & $\begin{array}{l}\text { High sensitivity to low } \\
\text { concentrations, } \\
\text { detection of different } \\
\text { structures }\end{array}$ & $\begin{array}{l}\text { Interference due } \\
\text { endogen adducts }\end{array}$ & \\
\hline & Immunoassays & Very high sensitivity & $\begin{array}{l}\text { Hard to obtain and } \\
\text { validate antibodies }\end{array}$ & \\
\hline $\begin{array}{l}\text { Primary } \\
\text { compound } \\
\text { detection }\end{array}$ & PAH molecules & Indicators of exposure & $\begin{array}{l}\text { Some compounds } \\
\text { are volatile }\end{array}$ & Pyrene \\
\hline $\begin{array}{l}\text { Polymorphism } \\
\text { analysis }\end{array}$ & Genotyping & Susceptibility markers & $\begin{array}{l}\text { Few studies on } \\
\text { populations }\end{array}$ & $\begin{array}{l}\text { CYP1A1 } \\
\text { polymorphisms }\end{array}$ \\
\hline $\begin{array}{c}\text { Gene } \\
\text { expression }\end{array}$ & $\begin{array}{l}\text { Molecular biology } \\
\text { methods }\end{array}$ & $\begin{array}{l}\text { Changes in gene } \\
\text { expression of some } \\
\text { genes are related with } \\
\text { PAH exposure }\end{array}$ & $\begin{array}{l}\text { Expensive and } \\
\text { highly skilled } \\
\text { techniques }\end{array}$ & CYP1B1 expression \\
\hline
\end{tabular}

Table 2. Methods to detect DNA damage caused by PAH exposure.

These studies offer novel alternatives for the prevention of further DNA damage caused by PAH exposure. Additionally, mechanisms of damage and repair are revealed through understanding the interactions and pathways involved when these molecules come into contact.

Both methods of detection and prevention of DNA damage are candidates for becoming new molecular alternatives for therapy and diagnosis of PAH-exposed individuals, and new tools in environmental biomonitoring.

\section{Conclusions}

Worldwide, the population is, to some extent, exposed to PAHs. Of primary concern are the carcinogenic, teratogenic and mutagenic properties exhibited by some PAHs. The 
occurrence of cancer and other diseases associated with PAH exposure has increased in recent decades. As we discussed in this chapter, the major mechanisms of carcinogenesis induced by these compounds are the interaction of PAHs with DNA to form adducts and the generation of reactive oxygen species. Both activities result in DNA damage and mutagenesis in important sites of the genome. Maintenance of genome integrity is critically dependent on efficient repair of DNA lesions by specific DNA repair mechanisms. In addition, the metabolism of PAHs is related with the ability of cells to prevent damage. Polymorphisms in DNA repair or xenobiotic metabolism-related genes are therefore associated with PAH-induced carcinogenesis. For this reason, understanding the metabolic pathways, biochemical transformations and interactions of PAHs with DNA will help to develop better strategies for risk analysis in exposed individuals. Some studies have shown that several natural compounds could help to reduce DNA damage caused by PAH exposure.

These findings offer the possibility for the development of novel drugs that help in the treatment of diseases related to $\mathrm{PAH}$ exposure. The analysis of specific polymorphisms of DNA repair genes will help to determine susceptibility in defined populations and the development of new biomarkers and diagnostic tools. Moreover, the study of DNA damage induced by these compounds has included other environmentally important species, such as fish, shrimp and worms. These studies are important in the development of biomarkers for biomonitoring and environmental assessment.

\section{Acknowledgments}

This work was supported by CONACyT Mexico (60463) to AA and CONACyT (104316) to BM.

\section{References}

Ali, D., Verma, A., Mujtaba, F., Dwivedi, A., Hans, R. K.\& Ray, R. S. (2011). UVB-induced apoptosis and DNA damaging potential of chrysene via reactive oxygen species in human keratinocytes. Toxicol Lett, Vol. 204, No.2-3, (Jul 28), pp. 199-207, 1879-3169 (Electronic) 0378-4274 (Linking)

An, J., Yin, L., Shang, Y., Zhong, Y., Zhang, X., Wu, M., Yu, Z., Sheng, G., Fu, J. \& Huang, Y. (2011). The combined effects of BDE47 and BaP on oxidatively generated DNA damage in L02 cells and the possible molecular mechanism. Mutation Research/Genetic Toxicology and Environmental Mutagenesis, Vol. In Press, Corrected Proof, pp.

ATSDR. (1996). ToxFAQs ${ }^{\mathrm{TM}}$ for Polycyclic Aromatic Hydrocarbons (PAHs), In: Agency for Toxic Substances and Disease Registry, 16.01.2011, Available from http:/ / www.atsdr.cdc.gov/toxfaqs/tf.asp?id=121\&tid=25

Bansal, S. K., Zaleski, J.\& Gessner, T. (1981). Glucuronidation of oxygenated benzo(a)pyrene derivatives by UDP-glucuronyltransferase of nuclear envelope. Biochemical and Biophysical Research Communications, Vol. 98, No.1, pp. 131-139,

Bennett, R. A., Wilson, D. M., 3rd, Wong, D. \& Demple, B. (1997). Interaction of human apurinic endonuclease and DNA polymerase beta in the base excision repair pathway. Proceedings of the National Academy of Sciences of the U S A, Vol. 94, No.14, (Jul 8), pp. 7166-7169, 0027-8424 (Print) 0027-8424 (Linking) 
Bhattacharyya, N. P., Maher, V. M.\& McCormick, J. J. (1989). Ability of structurally related polycyclic aromatic carcinogens to induce homologous recombination between duplicated chromosomal sequences in mouse $\mathrm{L}$ cells. Mutation Research/Fundamental and Molecular Mechanisms of Mutagenesis, Vol. 211, No.2, pp. 205-214,

Binkova, B., Chvatalova, I., Lnenickova, Z., Milcova, A., Tulupova, E., Farmer, P. B.\& Sram, R. J. (2007). PAH-DNA adducts in environmentally exposed population in relation to metabolic and DNA repair gene polymorphisms. Mutation Research/Fundamental and Molecular Mechanisms of Mutagenesis, Vol. 620, No.1-2, pp. 49-61,

Boffetta, P., Jourenkova, N.\& Gustavsson, P. (1997). Cancer risk from occupational and environmental exposure to polycyclic aromatic hydrocarbons. Cancer Causes Control, Vol. 8, No.3, (May), pp. 444-472, 0957-5243 (Print) 0957-5243 (Linking)

Bolognesi, C., Parrini, M., Aiello, C.\& Rossi, L. (1991). DNA damage induced by 7,12dimethylbenz[a]anthracene in the liver and the mammary gland of rats exposed to polycyclic aromatic hydrocarbon enzyme inducers during perinatal life. Mutagenesis, Vol. 6, No.2, (Mar), pp. 113-116, 0267-8357 (Print) 0267-8357 (Linking)

Bonner, M. R., Rothman, N., Mumford, J. L., He, X., Shen, M., Welch, R., Yeager, M., Chanock, S., Caporaso, N.\& Lan, Q. (2005). Green tea consumption, genetic susceptibility, PAH-rich smoky coal, and the risk of lung cancer. Mutat Res, Vol. 582, No.1-2, (Apr 4), pp. 53-60, 0027-5107 (Print) 0027-5107 (Linking)

Boysen, G.\& Hecht, S. S. (2003). Analysis of DNA and protein adducts of benzo[a]pyrene in human tissues using structure-specific methods. Mutation Research/Reviews in Mutation Research, Vol. 543, No.1, pp. 17-30,

Braithwaite, E., Wu, X.\& Wang, Z. (1998). Repair of DNA lesions induced by polycyclic aromatic hydrocarbons in human cell-free extracts: involvement of two excision repair mechanisms in vitro. Carcinogenesis, Vol. 19, No.7, (Jul), pp. 1239-1246, 01433334 (Print) 0143-3334 (Linking)

Briede, J. J., Godschalk, R. W., Emans, M. T., De Kok, T. M., Van Agen, E., Van Maanen, J., Van Schooten, F. J.\& Kleinjans, J. C. (2004). In vitro and in vivo studies on oxygen free radical and DNA adduct formation in rat lung and liver during benzo[a]pyrene metabolism. Free Radicals Research, Vol. 38, No.9, (Sep), pp. 9951002, 1071-5762 (Print)1029-2470 (Linking)

Buterin, T., Hess, M. T., Luneva, N., Geacintov, N. E., Amin, S., Kroth, H., Seidel, A.\& Naegeli, H. (2000). Unrepaired fjord region polycyclic aromatic hydrocarbon-DNA adducts in ras codon 61 mutational hot spots. Cancer Research, Vol. 60, No.7, (Apr 1), pp. 1849-1856, 0008-5472 (Print) 0008-5472 (Linking)

Castorena-Torres, F., Bermudez de Leon, M., Cisneros, B., Zapata-Perez, O., Salinas, J. E.\& Albores, A. (2008). Changes in gene expression induced by polycyclic aromatic hydrocarbons in the human cell lines HepG2 and A549. Toxicology In Vitro, Vol. 22, No.2, (Mar), pp. 411-421, 0887-2333 (Print)

Chan, H. Y., Wang, H., Tsang, D. S., Chen, Z. Y.\& Leung, L. K. (2003). Screening of chemopreventive tea polyphenols against $\mathrm{PAH}$ genotoxicity in breast cancer cells by a XRE-luciferase reporter construct. Nutrition and Cancer, Vol. 46, No.1, pp. 93100, 0163-5581 (Print) 0163-5581 (Linking) 
Chatgilialoglu, C.\& O'Neill, P. (2001). Free radicals associated with DNA damage. Experimental Gerontology, Vol. 36, No.9, (Sep), pp. 1459-1471, 0531-5565 (Print) 05315565 (Linking)

Chou, H. C., Ozawa, S., Fu, P. P., Lang, N. P.\& Kadlubar, F. F. (1998). Metabolic activation of methyl-hydroxylated derivatives of 7,12-dimethylbenz[a]anthracene by human liver dehydroepiandrosterone-steroid sulfotransferase. Carcinogenesis, Vol. 19, No.6, (Jun), pp. 1071-1076, 0143-3334 (Print) 0143-3334 (Linking)

Desler, C., Johannessen, C.\& Rasmussen, L. J. (2009). Repair of DNA damage induced by anthanthrene, a polycyclic aromatic hydrocarbon (PAH) without bay or fjord regions. Chemico-Biological Interactions, Vol. 177, No.3, (Feb 12), pp. 212-217, 18727786 (Electronic) 0009-2797 (Linking)

Dickey, C., Santella, R. M., Hattis, D., Tang, D., Hsu, Y., Cooper, T., Young, T. L.\& Perera, F. P. (1997). Variability in PAH-DNA adduct measurements in peripheral mononuclear cells: implications for quantitative cancer risk assessment. Risk Analysis, Vol. 17, No.5, (Oct), pp. 649-656, 0272-4332 (Print) 0272-4332 (Linking)

Eoff, R. L., Egli, M.\& Guengerich, P. (2010).Impact of Chemical Adducts on Translesion Synthesis in Replicative and Bypass DNA Polymerases From Structure to Function. In: The Chemical Biology of DNA damage Wiley-VCH Verlag GmbH \& Co. KGaA, 9783527630110,

EPA. (2009). List of Priority Chemicals, In: United States Environmental Protection Agency Web Site, 03.02.2011, Available from http://www.epa.gov/osw/hazard/wastemin/priority.htm

Fetzer, J. C.\& Biggs, W. R. (1994). A Review of the Large Polycyclic Aromatic Hydrocarbons. Polycyclic aromatic compounds, Vol. 4, No.1, pp. 3 - 17, 1040-6638 March 18, 2011

Geacintov, N. E., Cosman, M., Hingerty, B. E., Amin, S., Broyde, S.\& Patel, D. J. (1997). NMR Solution Structures of Stereoisomeric Covalent Polycyclic Aromatic CarcinogenDNA Adducts: Principles, Patterns, and Diversity. Chemical Research in Toxicology, Vol. 10, No.2, pp. 111-146,

Gray, D. L., Warshawsky, D., Xue, W., Nines, R., Wang, Y., Yao, R.\& Stoner, G. D. (2001). The effects of a binary mixture of benzo(a)pyrene and 7H-dibenzo(c,g)carbazole on lung tumors and K-ras oncogene mutations in strain A/J mice. Experimental Lung Research, Vol. 27, No.3, (Apr-May), pp. 245-253, 0190-2148 (Print) 0190-2148 (Linking)

Gu, A., Ji, G., Zhu, P., Zhou, Y., Fu, G., Xia, Y., Song, L., Wang, S. \& Wang, X. (2010). Nucleotide excision repair polymorphisms, polycyclic aromatic hydrocarbon exposure, and their effects on sperm deoxyribonucleic acid damage and male factor infertility. Fertility and Sterility, Vol. 94, No.7, pp. 2620-2625.e2625,

Guengerich, F. P. (2000). Metabolism of chemical carcinogens. Carcinogenesis, Vol. 21, No.3, (Mar), pp. 345-351, 0143-3334 (Print) 0143-3334 (Linking)

Hsu, G. W., Huang, X., Luneva, N. P., Geacintov, N. E.\& Beese, L. S. (2005). Structure of a high fidelity DNA polymerase bound to a benzo[a]pyrene adduct that blocks replication. Journal of Biological Chemistry, Vol. 280, No.5, (Feb 4), pp. 3764-3770, 0021-9258 (Print) 0021-9258 (Linking)

Hu, J. J., Hall, M. C., Grossman, L., Hedayati, M., McCullough, D. L., Lohman, K.\& Case, L. D. (2004). Deficient nucleotide excision repair capacity enhances human prostate 
cancer risk. Cancer Res, Vol. 64, No.3, (Feb 1), pp. 1197-1201, 0008-5472 (Print) 00085472 (Linking)

IARC. (2010). IARC monographs on the evaluation of carcinogenic risks to humans., In: International Agency for Research in Cancer Web site, 22.02.2011, Available from http://monographs.iarc.fr/ENG/Classification/index.php

Ichiba, M., Hagmar, L., Rannug, A., Hogstedt, B., Alexandrie, A. K., Carstensen, U.\& Hemminki, K. (1994). Aromatic DNA adducts, micronuclei and genetic polymorphism for CYP1A1 and GST1 in chimney sweeps. Carcinogenesis, Vol. 15, No.7, (Jul), pp. 1347-1352, 0143-3334 (Print) 0143-3334 (Linking)

Ji, G., Gu, A., Zhou, Y., Shi, X., Xia, Y., Long, Y., Song, L., Wang, S.\& Wang, X. (2010). Interactions between Exposure to Environmental Polycyclic Aromatic Hydrocarbons and DNA Repair Gene Polymorphisms on Bulky DNA Adducts in Human Sperm. PLoS ONE, Vol. 5, No.10, pp. e13145,

Jongeneelen, F. J. (2001). Benchmark guideline for urinary 1-hydroxypyrene as biomarker of occupational exposure to polycyclic aromatic hydrocarbons. Annals of Occupationa Hygiene, Vol. 45, No.1, (Jan), pp. 3-13, 0003-4878 (Print) 0003-4878 (Linking)

Karami, S., Boffetta, P., Brennan, P., Stewart, P. A., Zaridze, D., Matveev, V., Janout, V., Kollarova, H., Bencko, V., Navratilova, M., Szeszenia-Dabrowska, N., Mates, D., Gromiec, J. P., Sobotka, R., Chow, W.-H., Rothman, N.\& Moore, L. E. (2011). Renal Cancer Risk and Occupational Exposure to Polycyclic Aromatic Hydrocarbons and Plastics. Journal of Occupational \& Environmental Medicine, Vol. 53, No.2, pp. 218-223 1076-2752

Kim, J. H., Stansbury, K. H., Walker, N. J., Trush, M. A., Strickland, P. T.\& Sutter, T. R. (1998). Metabolism of benzo[a]pyrene and benzo[a]pyrene-7,8-diol by human cytochrome P450 1B1. Carcinogenesis, Vol. 19, No.10, (Oct), pp. 1847-1853, 0143-3334 (Print) 0143-3334 (Linking)

Kunkel, T. A.\& Erie, D. A. (2005). DNA mismatch repair. Annual Review of Biochemistry, Vol. 74, pp. 681-710, 0066-4154 (Print) 0066-4154 (Linking)

Lagerqvist, A., Hakansson, D., Frank, H., Seidel, A.\& Jenssen, D. (2011). Structural requirements for mutation formation from polycyclic aromatic hydrocarbon dihydrodiol epoxides in their interaction with food chemopreventive compounds. Food and Chemical Toxicology, Vol. 49, No.4, (Apr), pp. 879-886, 1873-6351 (Electronic) 0278-6915 (Linking)

Leung, H. Y., Yung, L. H., Poon, C. H., Shi, G., Lu, A. L.\& Leung, L. K. (2009). Genistein protects against polycyclic aromatic hydrocarbon-induced oxidative DNA damage in non-cancerous breast cells MCF-10A. British Journal of Nutrition, Vol. 101, No.2, (Jan), pp. 257-262, 1475-2662 (Electronic) 0007-1145 (Linking)

Leung, H. Y., Yung, L. H., Shi, G., Lu, A. L.\& Leung, L. K. (2009). The red wine polyphenol resveratrol reduces polycyclic aromatic hydrocarbon-induced DNA damage in MCF-10A cells. British Journal of Nutrition, Vol. 102, No.10, (Nov), pp. 1462-1468, 1475-2662 (Electronic) 0007-1145 (Linking)

Lin, C. H., Huang, X., Kolbanovskii, A., Hingerty, B. E., Amin, S., Broyde, S., Geacintov, N. E.\& Patel, D. J. (2001). Molecular topology of polycyclic aromatic carcinogens determines DNA adduct conformation: a link to tumorigenic activity. Journal of Molecular Biology, Vol. 306, No.5, pp. 1059-1080, 
Ling, H., Sayer, J. M., Plosky, B. S., Yagi, H., Boudsocq, F., Woodgate, R., Jerina, D. M.\& Yang, W. (2004). Crystal structure of a benzo[a]pyrene diol epoxide adduct in a ternary complex with a DNA polymerase. Proceedings of the National Academy of Sciences of the U S A, Vol. 101, No.8, (Feb 24), pp. 2265-2269, 0027-8424 (Print) 00278424 (Linking)

Meschini, R., Berni, A., Marotta, E., Filippi, S., Fiore, M., Mancinelli, P., Natarajan, A. T.\& Palitti, F. (2010). DNA repair mechanisms involved in the removal of DBPDEinduced lesions leading to chromosomal alterations in $\mathrm{CHO}$ cells. Cytogenetics and Genome Research, Vol. 128, No.1-3, pp. 124-130, 1424-859X (Electronic) 1424-8581 (Linking)

Monzo, M., Moreno, I., Navarro, A., Ibeas, R., Artells, R., Gel, B., Martinez, F., Moreno, J., Hernandez, R.\& Navarro-Vigo, M. (2007). Single nucleotide polymorphisms in nucleotide excision repair genes XPA, XPD, XPG and ERCC1 in advanced colorectal cancer patients treated with first-line oxaliplatin/fluoropyrimidine. Oncology, Vol. 72, No.5-6, pp. 364-370, 1423-0232 (Electronic) 0030-2414 (Linking)

Mordukhovich, I., Rossner, P., Jr., Terry, M. B., Santella, R., Zhang, Y. J., Hibshoosh, H., Memeo, L., Mansukhani, M., Long, C. M., Garbowski, G., Agrawal, M., Gaudet, M. M., Steck, S. E., Sagiv, S. K., Eng, S. M., Teitelbaum, S. L., Neugut, A. I., ConwayDorsey, K.\& Gammon, M. D. (2010). Associations between polycyclic aromatic hydrocarbon-related exposures and p53 mutations in breast tumors. Environmental Health Perspectives, Vol. 118, No.4, (Apr), pp. 511-518, 1552-9924 (Electronic) 00916765 (Linking)

NIST. (2010). NIST chemical kinetics model database., In: National Institute of Standards and Tecnonology database, 03.03.2011, Available from http:/ / kinetics.nist.gov/CKMech/SpeciesSearch.jsp\#Help PAH Class

Obolenskaya, M. Y., Teplyuk, N. M., Divi, R. L., Poirier, M. C., Filimonova, N. B., Zadrozna, M.\& Pasanen, M. J. (2010). Human placental glutathione S-transferase activity and polycyclic aromatic hydrocarbon DNA adducts as biomarkers for environmental oxidative stress in placentas from pregnant women living in radioactivity- and chemically-polluted regions. Toxicology Letters, Vol. 196, No.2, pp. 80-86,

Piipari, R., Savela, K., Nurminen, T., Hukkanen, J., Raunio, H., Hakkola, J., Mantyla, T., Beaune, P., Edwards, R. J., Boobis, A. R.\& Anttila, S. (2000). Expression of CYP1A1, CYP1B1 and CYP3A, and polycyclic aromatic hydrocarbon-DNA adduct formation in bronchoalveolar macrophages of smokers and non-smokers. International Journal of Cancer, Vol. 86, No.5, (Jun 1), pp. 610-616, 0020-7136 (Print) 0020-7136 (Linking)

Quinn, A. M., Harvey, R. G.\& Penning, T. M. (2008). Oxidation of PAH trans-Dihydrodiols by Human Aldo-Keto Reductase AKR1B10. Chemical Research in Toxicology, Vol. 21, No.11, pp. 2207-2215,

Quinn, A. M.\& Penning, T. M. (2006). Oxidation of PAH trans-dihydrodiols by human aldoketo reductase (AKR) 1B isoforms: A new AKR subfamily implicated in PAH activation. Proceedings of Frontiers in Cancer Prevention Research Conference, Boston, MA, USA, April 1, 2006

Rechkoblit, O., Zhang, Y., Guo, D., Wang, Z., Amin, S., Krzeminsky, J., Louneva, N.\& Geacintov, N. E. (2002). trans-Lesion synthesis past bulky benzo[a]pyrene diol epoxide N2-dG and N6-dA lesions catalyzed by DNA bypass polymerases. Journal 
of Biological Chemistry, Vol. 277, No.34, (Aug 23), pp. 30488-30494, 0021-9258 (Print) 0021-9258 (Linking)

Rojas, M., Cascorbi, I., Alexandrov, K., Kriek, E., Auburtin, G., Mayer, L., Kopp-Schneider, A., Roots, I.\& Bartsch, H. (2000). Modulation of benzo[a]pyrene diolepoxide-DNA adduct levels in human white blood cells by CYP1A1, GSTM1 and GSTT1 polymorphism. Carcinogenesis, Vol. 21, No.1, (Jan), pp. 35-41, 0143-3334 (Print) 0143-3334 (Linking)

Ross, J. A.\& Nesnow, S. (1999). Polycyclic aromatic hydrocarbons: correlations between DNA adducts and ras oncogene mutations. Mutation Research, Vol. 424, No.1-2, (Mar 8), pp. 155-166, 0027-5107 (Print) 0027-5107 (Linking)

Santodonato, J. (1997). Review of the estrogenic and antiestrogenic activity of polycyclic aromatic hydrocarbons: relationship to carcinogenicity. Chemosphere, Vol. 34, No.4, (Feb), pp. 835-848, 0045-6535 (Print) 0045-6535 (Linking)

Scicchitano, D. A. (2005). Transcription past DNA adducts derived from polycyclic aromatic hydrocarbons. Mutation Research, Vol. 577, No.1-2, (Sep 4), pp. 146-154, 0027-5107 (Print) 0027-5107 (Linking)

Shen, J., Desai, M., Agrawal, M., Kennedy, D. O., Senie, R. T., Santella, R. M. \& Terry, M. B. (2006). Polymorphisms in nucleotide excision repair genes and DNA repair capacity phenotype in sisters discordant for breast cancer. Cancer Epidemiology, Biomarkers \& Prevention, Vol. 15, No.9, (Sep), pp. 1614-1619, 1055-9965 (Print) 10559965 (Linking)

Shields, P. G., Sugimura, H., Caporaso, N. E., Petruzzelli, S. F., Bowman, E. D., Trump, B. F., Weston, A. \& Harris, C. C. (1992). Polycyclic aromatic hydrocarbon-DNA adducts and the CYP1A1 restriction fragment length polymorphism. Environ Health Perspect, Vol. 98, (Nov), pp. 191-194, 0091-6765 (Print) 0091-6765 (Linking)

Shimada, T. (2006). Xenobiotic-metabolizing enzymes involved in activation and detoxification of carcinogenic polycyclic aromatic hydrocarbons. Drug Metabolic Pharmacokinetics, Vol. 21, No.4, (Aug), pp. 257-276, 1347-4367 (Print) 1347-4367 (Linking)

Strickland, P. T., Kang, D., Bowman, E. D., Fitzwilliam, A., Downing, T. E., Rothman, N., Groopman, J. D. \& Weston, A. (1994). Identification of 1-hydroxypyrene glucuronide as a major pyrene metabolite in human urine by synchronous fluorescence spectroscopy and gas chromatography-mass spectrometry. Carcinogenesis, Vol. 15, No.3, (Mar), pp. 483-487, 0143-3334 (Print) 0143-3334 (Linking)

Sundberg, K., Dreij, K., Seidel, A. \& Jernström, B. (2002). Glutathione Conjugation and DNA Adduct Formation of Dibenzo[a,l]pyrene and Benzo[a]pyrene Diol Epoxides in V79 Cells Stably Expressing Different Human Glutathione Transferases. Chemical Research in Toxicology, Vol. 15, No.2, pp. 170-179,

Tang, D., Rundle, A., Mooney, L., Cho, S., Schnabel, F., Estabrook, A., Kelly, A., Levine, R., Hibshoosh, H.\& Perera, F. (2003). Sulfotransferase 1A1 (SULT1A1) Polymorphism, PAH-DNA Adduct Levels in Breast Tissue and Breast Cancer Risk in a CaseControl Study. Breast Cancer Research and Treatment, Vol. 78, No.2, pp. 217-222,

Vodicka, P., Kumar, R., Stetina, R., Sanyal, S., Soucek, P., Haufroid, V., Dusinska, M., Kuricova, M., Zamecnikova, M., Musak, L., Buchancova, J., Norppa, H., Hirvonen, A., Vodickova, L., Naccarati, A., Matousu, Z.\& Hemminki, K. (2004). Genetic 
polymorphisms in DNA repair genes and possible links with DNA repair rates, chromosomal aberrations and single-strand breaks in DNA. Carcinogenesis, Vol. 25, No.5, (May), pp. 757-763, 0143-3334 (Print) 0143-3334 (Linking)

Wang, Z. Y., Khan, W. A., Bickers, D. R.\& Mukhtar, H. (1989). Protection against polycyclic aromatic hydrocarbon-induced skin tumor initiation in mice by green tea polyphenols. Carcinogenesis, Vol. 10, No.2, (Feb), pp. 411-415, 0143-3334 (Print) 0143-3334 (Linking)

Williams, J. A.\& Phillips, D. H. (2000). Mammary expression of xenobiotic metabolizing enzymes and their potential role in breast cancer. Cancer Research, Vol. 60, No.17, (Sep 1), pp. 4667-4677, 0008-5472 (Print) 0008-5472 (Linking)

Yoon, J. H., Lee, C. S.\& Pfeifer, G. P. (2003). Simulated sunlight and benzo[a]pyrene diol epoxide induced mutagenesis in the human p53 gene evaluated by the yeast functional assay: lack of correspondence to tumor mutation spectra. Carcinogenesis, Vol. 24, No.1, (Jan), pp. 113-119, 0143-3334 (Print) 0143-3334 (Linking)

$\mathrm{Yu}, \mathrm{M.-H}$. (2005).Environmental toxicology: biological and health effects of pollutants (2nd), CRC Press, 156670670X (alk. paper), Boca Raton

Zang, H., Chowdhury, G., Angel, K. C., Harris, T. M.\& Guengerich, F. P. (2006). Translesion synthesis across polycyclic aromatic hydrocarbon diol epoxide adducts of deoxyadenosine by Sulfolobus solfataricus DNA polymerase Dpo4. Chemical Research in Toxicology, Vol. 19, No.6, (Jun), pp. 859-867, 0893-228X (Print) 0893-228X (Linking)

Zhong, Q., Amin, S., Lazarus, P.\& Spratt, T. E. (2010). Differential repair of polycyclic aromatic hydrocarbon DNA adducts from an actively transcribed gene. DNA Repair (Amsterdam), Vol. 9, No.9, (Sep 4), pp. 1011-1016, 1568-7856 (Electronic) 15687856 (Linking)

Zienolddiny, S., Ryberg, D., Svendsrud, D. H., Eilertsen, E., Skaug, V., Hewer, A., Phillips, D. H., te Riele, H.\& Haugen, A. (2006). Msh2 deficiency increases susceptibility to benzo[a]pyrene-induced lymphomagenesis. International Journal of Cancer, Vol. 118, No.11, (Jun 1), pp. 2899-2902, 0020-7136 (Print) 0020-7136 (Linking) 


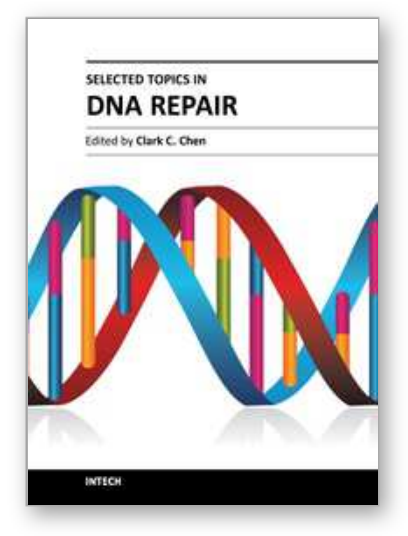

\author{
Selected Topics in DNA Repair \\ Edited by Prof. Clark Chen
}

ISBN 978-953-307-606-5

Hard cover, 572 pages

Publisher InTech

Published online 26, October, 2011

Published in print edition October, 2011

This book is intended for students and scientists working in the field of DNA repair, focusing on a number of topics ranging from DNA damaging agents and mechanistic insights to methods in DNA repair and insights into therapeutic strategies. These topics demonstrate how scientific ideas are developed, tested, dialogued, and matured as it is meant to discuss key concepts in DNA repair. The book should serve as a supplementary text in courses and seminars as well as a general reference for biologists with an interest in DNA repair.

\title{
How to reference
}

In order to correctly reference this scholarly work, feel free to copy and paste the following:

Balam Muñoz and Arnulfo Albores (2011). DNA Damage Caused by Polycyclic Aromatic Hydrocarbons: Mechanisms and Markers, Selected Topics in DNA Repair, Prof. Clark Chen (Ed.), ISBN: 978-953-307-606-5, InTech, Available from: http://www.intechopen.com/books/selected-topics-in-dna-repair/dna-damage-causedby-polycyclic-aromatic-hydrocarbons-mechanisms-and-markers

\section{INTECH}

open science | open minds

\author{
InTech Europe \\ University Campus STeP Ri \\ Slavka Krautzeka 83/A \\ 51000 Rijeka, Croatia \\ Phone: +385 (51) 770447 \\ Fax: +385 (51) 686166 \\ www.intechopen.com
}

\author{
InTech China \\ Unit 405, Office Block, Hotel Equatorial Shanghai \\ No.65, Yan An Road (West), Shanghai, 200040, China \\ 中国上海市延安西路65号上海国际贵都大饭店办公楼 405 单元 \\ Phone: +86-21-62489820 \\ Fax: $+86-21-62489821$
}


(C) 2011 The Author(s). Licensee IntechOpen. This is an open access article distributed under the terms of the Creative Commons Attribution 3.0 License, which permits unrestricted use, distribution, and reproduction in any medium, provided the original work is properly cited. 